\title{
Ischaemic colitis: two distinct patterns of severity
}

Ischaemic colitis accounts for only a small percentage ( 1 to $2 \%$ ) of patients with colonic pathology seen in gastrointestinal and surgical wards. Because its presentation is non-specific and as numerous conditions may favour its development, ischaemic colitis is probably frequently misdiagnosed and its incidence underestimated.

At presentation, the severity of early stage disease may vary considerably with the prevalent benign 'transient' forms being amenable to conservative regimens and the severe 'gangrenous' forms, requiring surgery. ${ }^{15}$ The percentage of surgical cases in a given series ranges widely (from $2^{6}$ to $42 \%$ ). ${ }^{7}$ These differences have been referred to repeatedly ${ }^{248}$ since the key report by Marston et al in 1966 (these authors also specify a third category, ischaemic stricture; however, this will not be dealt with here because, even if it does exist, ${ }^{9}$ it will only be diagnosed at a later date). ${ }^{1}$

This review covers diagnosis, predisposing factors, lesion distribution, treatment, and results. It is based on reports (in the literature) and our own six year series of 34 patients of which 13 were treated surgically and 21 conservatively. ${ }^{35}$

\section{Diagnosis}

Ischaemic colitis should be suspected in patients presenting with abdominal pain and rectal bleeding. ${ }^{12}{ }^{10} 11$ In practice, a correct diagnosis is usually made 'after the ischaemic episode is over' ${ }^{2}$ but this is only possible in mild 'transient' cases ${ }^{19}$ in which a conservative approach can be adopted until a complete investigation is carried out.

No test specific for ischaemic colitis has yet been developed. ${ }^{12}$ Enzyme determinations are routinely used in the assessment of cardiac or hepatic necrosis, but we still have no specific and early marker of intestinal viability. ${ }^{13}$ Ischaemic colitis is usually diagnosed on the basis of a heterogeneous collection of clinical, radiological, endoscopic and pathological evidence. ${ }^{14}$ Radiological evidence includes 'thumb printing,' 'saw toothing,' tubular narrowing, and thickened mucosal folds but is not always sufficient to make a firm diagnosis of ischaemic colitis. ${ }^{1}$ Contrast studies should be obtained early as certain indicative images may be transient. ${ }^{2}$ Endoscopy may include (in addition to pathognomonic but inconstant submucous haematoma) mucosal loss or other changes (fragility, oedema, hypervascularisation) and even ulceration and pseudomembranes. Skip lesions ${ }^{15}$ are rare, ${ }^{11}$ and progression to other colonic segments unusual. ${ }^{9}$ Pathological findings ${ }^{16}{ }^{17}$ are seldom unequivocal, ${ }^{18} 19$ except for images of patchy tubular atrophy ${ }^{20}$ or superficial coagulation necrosis. ${ }^{21}$ Biopsy usually involves only superficial mucosal fragments and therefore yields no information on the depth of ischaemic involvement.

Whether radiology or endoscopy ${ }^{4}$ is superior for the diagnosis of these benign forms of ischaemic colitis is uncertain. Angiography seems an attractive option but the information it provides is seldom decisive, $28914192022-24$ probably because the lesions are very peripheral and therefore difficult to detect.

Computerised tomography ${ }^{2526}$ is unlikely to provide useful diagnostic information, but it may help in assessing intra or retroperitoneal involvement and consequently disease severity in much the same way as it is now used in acute colonic diverticulitis. ${ }^{27}$ The same problems apply to indium-111 labelled leucocytes which are useful for preoperative determination of the site and extent of the disease. ${ }^{28}$

Severe forms of ischaemic colitis require surgery, usually without delay. " Preoperative diagnosis is often incorrect, however, because of insufficient time for evaluation; this occurred in eight of 13 cases in our series. Gastrografin enema offers the promise of higher diagnostic yield and, in view of its peritoneal tolerance can be used even when perforation is suspected.

\section{Aetiological aspects}

The key role is a sudden fall of colonic blood supply. ${ }^{1929}$ The mechanism is illustrated clearly by those cases of ischaemic colitis (no more than 2\%) ) $^{19} 31$ that follow abdominal aorta reconstruction $^{210}$ - which is more common when aortic repair is undertaken as an emergency. ${ }^{1023}$ Ligation of a patent inferior mesenteric artery does not seem decisive per se in the development of ischaemic colitis. ${ }^{3+}$

Regional low flow is the crucial factor in ischaemic colitis and is more likely where there has been previous impaired regional vascularisation. This impairment, however, is not an essential prerequisite as ischaemic colitis has been reported in healthy young joggers, ${ }^{35}$ occasionally severe enough to require subtotal colectomy.$^{37}$ Intermediate pathogenic phases include hyperthermia, dehydration, and splanchnic vasoconstriction. It is not clear why the colon is preferentially affected in healthy individuals since other abdominal organs such as the pancreas are more sensitive to hypovolaemia. ${ }^{38-40}$

Blood deprivation may occasionally be of embolic origin including cholesterol emboli ${ }^{41}{ }^{42}$ and sickle cell crises. ${ }^{43}$ Other conditions (drugs or diseases) may favour or cause ischaemic colitis. $^{2111744}$

Whatever the exact pathophysiological mechanism, ischaemic colitis is favoured by atheroslerosis or vasculitis. Most patients with ischaemic colitis are elderly probably as a result of the presence of atherosclerosis in this age group. The severity of ischaemic colitis might be directly related to the extent of atherosclerosis; in our series, cardiovascular conditions were far more frequent in the group requiring surgical exploration: eight of 13 operated patients suffered from atherosclerosis (three with a history of coronary heart disease, two with intermittent claudication, one 'stroke,' one Buerger's disease, and one cardiac insufficiency; two others developed ischaemic colitis after aortic reconstruction for ruptured aneurysms). ${ }^{3}$ The corresponding figure in the conservative group was only four of 21 patients.

\section{Site of ischaemic lesions}

Involvement of the splenic flexure in ischaemic colitis is explained by the weakness of the arc of Riolan (marginal artery of Drummond), located at the peripheral junction of the superior and inferior mesenteric arteries. ${ }^{456}$ This site was found 22 times in our series; it was never isolated and was usually associated with involvement of the descending colon (20 cases). The rectum is seldom involved' even though it shares a similar precarious vascularisation at the tip of the hypogastric and inferior mesenteric territories. ${ }^{18}$

The rare reports of ascending colon involvement ${ }^{4}{ }^{101529}$ are 
mainly in young patients. ${ }^{47}$ Involvement of the ascending colon might well be a characteristic of the more severe forms of ischaemic colitis as it was implicated in eight of our operated cases ( $v$ only four of 21 in the conservative group).

\section{Treatment and results}

Most cases of ischaemic colitis (nearly two-thirds in our series) do not present peritoneal signs of sufficient severity to warrant surgical exploration. ${ }^{7+8}$ Mortality is low and the deaths that do occur are usually the consequence of selection biases or of a distinct superimposed pathology, not colitis per se: the highest reported mortality (eight of 19 patients treated conservatively - that is, $42 \%$ ) was in a series in which five patients refused surgery and two were moribund. ${ }^{10}$ Minor forms should respond well to simple conservative regimens such as bed rest, nil by mouth, intravenous hydration, and broad spectrum antibiotics. ${ }^{1+16}$ In addition, medication known or suspected to cause mesenteric vasoconstriction should be withdrawn. ${ }^{2}$ None of the measures known to enhance splanchnic circulation or reduce viscosity - for example, anticoagulants, plasma expanders, vasodilators, rachianaesthaesia, etc) have yet gained wide acceptance. Clinical resolution has occasionally been seen within 24 hours, ${ }^{7}$ and complete clinical and radiological resolution is usually noted within one to two weeks. ${ }^{2+29}$

Surgical treatment is indicated for severe forms of ischaemic colitis in the acute phase with resection of the ischaemic colon, as there is nearly always transparietal necrosis, with optimal assessment of residual colon viability.

A range of devices have been constructed to supplement intraoperative examination or palpation but all may give misleading results. ${ }^{2915}$ None is perfect and most have limited use in practice..$^{49}$ Doppler ultrasound, for instance, has the advantage of simplicity but does not quantify blood supply, and is thus 'inadequate to allow identification of critical levels of tissue ischaemia." Although its application requires minute care, sigmoid intramural $\mathrm{pH}$ monitoring seems, so far, to most accurately predict the development of ischaemic colitis during abdominal aorta surgery. ${ }^{34} 50$

In practice, in case of doubt, colonic resection should be extensive, in particular because tolerance is usually good. Immediate restoration of continuity is obviously appealing for both patient and surgeon, but can be a difficult decision to take. ${ }^{15}$ Second look laparotomy and laparostomy ${ }^{51}$ have been instrumental in reducing mortality in gangrenous ischaemic colitis ${ }^{410}$ from an unacceptable level of $70 \%{ }^{15}$; they might also have the merit of allowing normally unacceptable anastomoses in an unpropitious abdominal environment. In case of doubt or of frank peritonitis (perforation was encountered in $15 \%$ of our operated cases), however, it seems advisable to avoid primary anastomosis ${ }^{10}$ and limit oneself to Hartmann type resection and proximal stomy.

There may be a place for early laparoscopy because, at onset, severe forms of ischaemic colitis may occasionally appear as falsely reassuring and result in undue delay in treatment during which time total colonic disintegration may occur.

\section{Conclusion}

Approximately two-thirds of ischaemic colitis patients respond favourably and rapidly to such simple conservative measures as fasting, hydration, and antibiotics. The remaining third (many of whom will have concomittant patent underlying cardiovascular disease and right sided colonic involvement) require early surgical exploration, without, in most cases, the benefit of established preoperative diagnosis. Treatment entails, basically, resection of all ischaemic colon.
The authors would like to thank Mr David W Reed for reviewing the manuscript and Dr René Prêtre for his comments.

J H ROBERT

G MENTHA

A ROHNER

Division of Digestive Surgery,

Geneva University Hospital,

CH-1211 Geneva 4,

Switzerland

1 Marston A, Pheils MT, Thomas ML, Morson BC. Ischaemic colitis. Gut 1966; $7: 1-15$

Kaleya RN, Boley SJ. Colonic ischemia. In: Fazio VW, ed. Current therapy in colon and rectal surgery. Toronto: BC Decker, 1990: 324-9.

3 Mentha G, Robert J, Rohner A. Résultats du traitement chirurgical de la colite ischémique. Helv Chir Acta 1990; 57: 777-82.

4 Parish KL, Chapman WC, Williams LF. Ischemic colitis. An ever-changing spectrum? Am Surg 1991; 57: 118-21.

5 Robert J, Mentha G, Dederding JP, Rohner A. La colite ischémique. Résultats du traitement conservateur. Schweiz Med Wochenschr 1991; 121: 913-6.

6 Marcuson RW. Ischemic colitis. Clin Gastroenterol 1972; 1: 743-63.

7 Barcewicz OPA, Welch JP. Ischaemic colitis in young patients. Dis Colon Rectum 1980; 23: 109-14.

8 de Dombal FT, Fletcher DM, Harris RS. Early diagnosis of ischaemic colitis. Gut 1969; 10: 131-4.

9 Williams LF, Wittenberg J. Ischemic colitis: a useful clinical diagnosis, but is it ischemic? Ann Surg 1975; 182: 439-48.

10 Guttormson NL, Bubrick MP. Mortality from ischemic colitis. Dis Colon Rectum 1989; 32: 469-72.

11 Petit A, Guénon C, Duhamel C, Lerebours E, Colin R. Colites ischémiques 'ambulatoires'. Gastroentérol Clin Biol 1990; 14: 739-43.

12 Abel ME, Russell TR. Ischemic colitis. Comparison of surgical and nonoperative management. Dis Colon Rectum 1983; 26: 113-5.

13 Thompson JS, Bragg LE, West WW. Serum enzyme levels during intestinal ischemia. Ann Surg 1990; 211: 369-73.

14 Williams LF, Bosniak MA, Wittenberg J, Manuel B, Grimes ET, Byrne JJ Ischemic colitis. Am F Surg 1969; 117: 254-64.

15 Sakai L, Keltner R, Kaminski D. Spontaneous and shock-associated ischemic colitis. Am $\mathcal{F}$ Surg 1980; 140: 755-60.

16 Whitehead R. The pathology of intestinal ischemia. Clin Gastroenterol 1972; 1 613-37.

17 Price AB. Ischemic colitis. In: Williams GT, ed. Gastrointestinal pathology. Berlin: Springer-Verlag, 1990: 229-46.

18 Ockner RK. Vascular diseases of the bowel. In: Sleisenger MH, Fordtran JS, eds. Gastrointestinal disease. Pathology, diagnosis, management. Philadelphia: W B Saunders, 1978: 1903-6.

19 Goligher J, Duthie H, Nixon H. Ischaemic colitis. In: Surgery of the anus, rectum and colon. London: Baillière Tindall, 1985: 1068-74.

20 Hemet J, Metayer J, Lemoine F, Laquerrière A, Elmaleh AM. Les colites ischémiques transitoires. Valeur diagnostique de l'atrophie épithéliale en aires. Ann Pathol (Paris) 1989; 9: 33-7.

21 Balaton AJ. Colite ischémique: le point de vue de l'anatomopathologiste. Ann Gastroentérol Hépatol 1990; 26: 17-9.

22 Dudley HAF, Faris I. Ischaemic colitis without predisposing cause. BM 71971 iii: 637-8.

23 Bookstein JJ. Non-occlusive ischemic colitis: angiographic aspects in a canine model. Invest Radiol 1978; 13: 506-13.

24 Cohn I, Nance FC. Mechanical, inflammatory, vascular, and miscellaneous benign lesions. In: Sabiston DC, ed. Davis Christopher textbook of surgery. The biological basis of modern surgical practice. Philadelphia: W B Saunders, 1981: biologice

25 Jones B, Fishman EK, Siegelmann SS. Ischemic colitis demonstrated by computed tomography. $\mathcal{F}$ Comput Assist Tomogr 1982; 6: 1120-3.

26 Federle MP.Chun G, Jeffrey RB, Rayor R. Computed tomographic findings in bowel infarction. ARF 1984; 142: 91-5.

27 Ambrosetti P, Robert J,Witzig JA, et al. Prognostic factors from computed tomography in acute left colonic diverticulitis. Brf S urg 1992; 79: 117-9.

28 Vijayakumar V, Bekerman C, Blend MJ. Preoperative prediction of extent and severity of ischemic colitis by imaging with In-111 labeled leukocytes. Clin Nucl Med 1991; 16: 98-102.

29 Boley SJ, Schwartz S, Lash J, Sternhill V. Reversible vascular occlusion of the colon. Surg Gynecol Obstet 1963; 113: 53-60.

$30 \mathrm{Johnston} \mathrm{KW.} \mathrm{Multicenter} \mathrm{prospective} \mathrm{study} \mathrm{of} \mathrm{nonruptured} \mathrm{abdominal} \mathrm{aortic}$ aneurysm. Part II. Variables predicting morbidity and mortality. 7 Vasc Surg 1989; 9: 437-47.

31 Brewster DC, Franklin DP, Cambria RP, et al. Intestinal ischemia complicating abdominal aortic surgery. Surgery 1991; 109: 447-54.

32 Vohra R, Abdool-Carim A, Groome J, Pollock JG. Anévrysmes aortiques rompus: complications post-opératoires et leur traitement. Ann Chir Vas rompus: complica

33 Maupin GE, Rimar SD, Villalba $M$. Ischemic colitis following abdominal aortic reconstruction for ruptured aneurysm. A 10-year experience. Am Surg 1989 55: $378-80$.

34 Schiedler MG, Cutler BS, Fiddian-Green RG. Sigmoid intramural pH for prediction of ischemic colitis during aortic surgery. A comparison with risk factors and inferior mesenteric artery stump pressures. Arch Surg 1987; 122 $881-6$.

35 Fogoros RN. 'Runner's trots'. Gastrointestinal disturbances. FAMA 1980 243: $1743-4$.

36 Heer M, Repond F, Hany A, Sulser H, Kehl O, Jäger K. Acute ischaemic colitis in a female long distance runner. Case report. Gut 1987; 28: 896-9.

37 Amoyal P, Bories P, Lyonnet P, Avril P, Barnéon G, Potet F, et al. Colectomie subtotale pour colite ischémique nécrosante chez un coureur de fond. Gastroentérol Clin Biol 1989; 13: 430.

38 Slater GI, Vladeck BC, Bassin R, Kark AE, Shoemaker WC. Sequential changes in distribution of cardiac output in hemorrhagic shock. Surgery 1973; 73: 714-22.

39 Dreiling DA, Robert JH, Toledano AE. Vascular pancreatitis. A clinical entity of growing importance. F Clin Gastroenterol 1988; 3: 3-6.

40 Robert JH, Toledano AE, Toth LS, Premus G, Dreiling DA. Hypovolemic 
shock, pancreatic blood flow, and pancreatitis. Intern $\mathcal{F}$ Pancreatol 1988; 3: 283-92.

41 Socinski MA, Frankel JP, Morrow PL, Krawitt EL, Painless diarrhea secondary to intestinal ischemia. Diagnosis of atheromatous emboli by jejunal biopsy. Dig Dis Sci 1984; 29: 674-7.

42 Moolenaar W, Kreuning J, Eulderink F, Lamers CBHW. Ischemic colitis and acalculous necrotizing cholecystitis as rare manifestations of cholesterol emboli in the same patient. Am 7 Gastroenterol 1989; 84: 1421-2

43 Gage TP, Gagnier JM. Ischemic colitis complicating sickle cell crisis. Gastroenterology 1983; 84: $171-4$.

44 Travis S, Davies DR, Creamer B. Acute colorectal ischaemia after anaphylactoid shock. Gut 1991; 32: 443-6.

45 Courbier R, Jausseran JM, Reggi M. L'arcade de Riolan: signification hémodynamique - déductions thérapeutiques. Schweiz Med Wochenschr 1976; 106: 363-7.
46 Binns JC, Isaacson P. Age-related changes in the colonic blood supply: their relevance to ischaemic colitis. Gut 1978; 19: 384-90.

47 Clark AW, Lloyd-Mostyn RH, Sadler MR. 'Ischaemic' colitis in young adults. BM7 1972; iv: 70-2.

48 Ross ST. Ischemic colitis. Postgrad Med 1972; 51: 71-4.

49 Galandiuk S, Fazio VW, Petras RE. Fluorescein endoscopy: a technique for noninvasive assessment of intestinal ischemia. Dis Colon Rectum 1988; 31 : 848-53.

50 Senagore A, Milsom JW, Walshaw RK, Dunstan R, Mazier WP, Chaudry IH Intramural $\mathrm{pH}$ : a quantitative measurement for predicting colorectal anastomotic healing. Dis Colon Rectum 1990; 33: 175-9.

51 Meyer P, von Segesser L, Jeanjacquot A, Rohner A. A new abdominal drain for overflowing lavage in instances of severe pancreatitis with persistent peritoneal contamination. Surg Gynecol Obstet 1987; 165: 271- 